\title{
Hubungan Tingkat Pendidikan dan Pekerjaan dengan Tingkat Pengetahuan Mengenai Kanker Ovarium pada Wanita
}

\author{
Association of Education Level and Occupation with Knowledge Level of Ovarian Cancer
}

\author{
Mitayani Purwoko
}

Fakultas Kedokteran Universitas Muhammadiyah Palembang

\section{DATA NASKAH:}

Received: 17 Mar 2018

Reviewed: 18 Apr 2018

Revised: 09 May 2018

Accepted: 10 Jun 2018

*KORESPONDENSI:

mitayani.dr@gmail.com

DOI:

10.18196/mm.180214

TIPE ARTIKEL:

Penelitian

\begin{abstract}
Abstrak: Kanker ovarium adalah tumor ganas yang berasal dari ovarium dengan berbagai tipe histologi yang dapat mengenai semua umur. Kanker ovarium menempati posisi ke-3 dari 10 kanker tersering pada wanita. Minimnya pengetahuan terhadap kanker sendiri merupakan salah satu penghambat pendeteksian dini kejadian kanker ovarium. Tujuan penelitian ini adalah untuk mengetahui hubungan antara tingkat pendidikan dan pekerjaan dengan tingkat pengetahuan wanita terkait kanker ovarium.Penelitian ini merupakan penelitian deskriptif observasional dengan desain cross sectional. Populasi penelitian ini adalah penduduk kota Palembang yang berjenis kelamin wanita. Besar sampel 80 orang diperoleh dengan teknik pengambilan sampel stratified random sampling. Data diambil menggunakan instrumen kuesioner mengenai pengetahuan wanita terkait kanker ovarium. Data dianalisis dengan uji Chi Square. Hasil penelitian menunjukkan bahwa $80 \%$ subjek memiliki pengetahuan yang kurang mengenai kanker ovarium dan 20\% memiliki pengetahuan cukup. Tidak ada subjek penelitian yang memiliki tingkat pengetahuan yang baik mengenai kanker ovarium. Hubungan tingkat pendidikan dengan tingkat pengetahuan responden mengenai kanker ovarium memiliki nilai $r=8,205$ dengan $p=0,038$. Hubungan pekerjaan dengan tingkat pengetahuan responden mengenai kanker ovarium memiliki nilai $r=3,156$ dengan $p=0,093$. Disimpulkan bahwa tingkat pengetahuan mengenai kanker ovarium dipengaruhi oleh tingkat pendidikan.
\end{abstract}

Kata kunci: Kanker Ovarium; Pengetahuan Kanker; Kewaspadaan Kanker Ovarium

\footnotetext{
Abstract: Ovarian cancer is a malignant tumor arise from ovarian tissue with various hystologic type that could happens at every age. Ovarian cancer was the third most common cancer in female. Awareness of ovarian cancer among women may lead to early detection and treatment of ovarian cancer. This study was aimed to find the association between education level and occupation with the level of knowledge about ovarian cancer. This was an observationaldescriptive study with cross sectional design. Study population was females in Palembang city. Sample size was 80 subjects, collected by stratified random sampling technique. Questions about awareness of ovarian cancer were administered to all subjects. This study showed that $80 \%$ of subjects was having poor knowledge and $20 \%$ was having sufficient knowledge about ovarian cancer. No subject had good knowledge of ovarian cancer. This study found an association between education level and knowledge level about ovarian cancer $(r=8,205 p=0.038)$ but found no association between occupation and knowledge level $(r=3,156 p=0.093)$. Conclusion, awareness of ovarian cancer was influenced by education level.
} 
Key words: Ovarian Cancer; Knowledge of Cancer; Awareness of Ovarian Cancer

\section{PENDAHULUAN}

Kanker adalah pertumbuhan jaringan yang ganas yang terdiri dari sel-sel epitelial yang cenderung menginfiltrasi jaringan sekitarnya dan menimbulkan metastasis. ${ }^{1}$ Kanker terbanyak pada perempuan adalah kanker serviks, lalu kanker payudara, kanker colon-rektum, kanker paru, kanker ovarium, dan kanker lambung. ${ }^{2}$ Kanker ovarium adalah tumor ganas yang berasal dari ovarium dengan berbagai tipe histologi yang dapat mengenai semua umur. $^{3}$ Kanker ovarium menempati posisi ke-3 dari 10 kanker tersering pada wanita. ${ }^{4}$

Data penderita kanker ovarium di RS Cipto Mangunkusumo Jakarta selama tahun 1996-2001 adalah 218 orang. ${ }^{5}$ Menurut data Kementerian Kesehatan RI, jumlah kasus baru kanker ovarium di RS Kanker Dharmais Jakarta pada tahun 2013 adalah 134 kasus dengan jumlah kematian sebesar 46 kasus. 6

Terjadinya kanker ovarium sampai sekarang tidak diketahui secara pasti etiologinya. Akan tetapi, berdasarkan penelitian yang ada, terdapat beberapa faktor yang dapat mempengaruhi terjadinya kanker ovarium. Faktor risiko tersebut yaitu usia yang produktif dan meningkat pada usia premenopause, indeks masa tubuh (IMT) yang berlebih, wanita yang tidak pernah mengalami kehamilan dan jumlah paritas, riwayat pembedahan ginekologi, terapi hormon estrogen, riwayat keluarga dengan kanker, serta konsumsi alkohol dan rokok. Selain itu, terdapat penelitian yang menyatakan bahwa faktor risiko kanker ovarium terbagi atas 5 bagian besar yaitu faktor reproduksi (jumlah paritas \& kehamilan, laktasi, serta usia menarke dan menopause), hormon eksogen (kontrasepsi hormonal, obat penyubur, dan terapi hormon pengganti), kondisi terkait ginekologi (endometriosis, PID (pelvic inflamematory disease) dan polycystic ovarian syndrome, faktor lingkungan, dan faktor genetik. Namun ada yang menyatakan bahwa berdasarkan hasil penelitian dan pembahasan, ditemukan bahwa umur menarke dini, jumlah paritas, riwayat keluarga, dan IMT yang overweight memiliki besar risiko yang bermakna terhadap kejadian kanker ovarium. Sementara paritas memiliki risiko yang tidak bermakna terhadap kejadian kanker ovarium. ${ }^{7,8,9}$

Kasus kanker yang ditemukan pada sta-dium dini serta mendapat pengobatan yang cepat dan tepat akan memberikan kesembuhan dan hara-pan hidup lebih lama. Oleh karena itu, penting dilakukan upaya pencegahan dan deteksi dini kanker. Minimnya pengetahuan terhadap kanker sendiri merupakan salah satu penghambat pendeteksian dini kejadian kanker ovarium.

Penelitian ini bertujuan untuk mengetahui hubungan antara tingkat pendidikan dan pekerjaan dengan tingkat pengetahuan wanita terkait kanker ovarium.

\section{BAHAN DAN CARA}

Penelitian ini merupakan penelitian deskriptif observasional dengan cross sectional. Penelitian telah dilaksanakan pada bulan Desember 2016 di Kelurahan 14 Ulu, Kecamatan Seberang Ulu II, Palembang. Populasi penelitian ini adalah penduduk kota Palembang yang berjenis kelamin wanita. Besar sampel 80 orang diperoleh dengan teknik pengambilan sampel stratified random sampling.

Data diambil menggunakan instrumen kuesioner yang berisikan pertanyaan mengenai pengetahuan wanita terkait kanker ovarium. Setiap pertanyaan telah diberi poin oleh peneliti. Pengetahuan dikategorikan baik bila memperoleh skor 76$100 \%$ dari total nilai, cukup bila $56-75 \%$ dari total nilai, serta kurang bila $<56 \%$ dari total nilai. Kuesioner telah melalui uji validitas terlebih dahulu menggunakan software komputer. Dalam penelitian ini, pengujian validitas dilakukan terhadap 20 responden. Pertanyaan dianggap valid apabila nilai $r_{\text {hitung }}>r_{\text {tabel }}$ untuk $\mathrm{df}=20-2=18$ dengan nilai $\alpha=0,05$ adalah 0,378 .

Nilai reliabilitas Alpha Cronbach adalah 0,722. $\mathrm{Hal}$ ini menunjukkan kuesioner sudah reliabel untuk digunakan dalam penelitian.

Hubungan antara tingkat pendidikan dan pekerjaan responden terhadap tingkat pengetahuan dianalisis menggunakan uji Chi square.

Tabel 1. Hasil uji validitas kuesioner

\begin{tabular}{cccc}
\hline Butir & $\mathrm{r}_{\text {hitung }}$ & $\mathrm{r}_{\text {tabel }}$ & Kriteria \\
\hline 1 & 0,650 & 0,378 & valid \\
2 & 0,519 & 0,378 & valid \\
3 & 0,528 & 0,378 & valid \\
4 & 0,486 & 0,378 & valid \\
5 & 0,845 & 0,378 & valid \\
6 & 0,449 & 0,378 & valid \\
7 & 0,561 & 0,378 & valid \\
8 & 0,618 & 0,378 & valid \\
\hline
\end{tabular}


HASIL

Kuesioner yang disebarkan memiliki 8 pertanyaan mengenai definisi ovarium, jumlah ovarium yang dimiliki perempuan, lamanya siklus menstruasi, definisi kanker ovarium, faktor risiko kanker ovarium, gejala kanker ovarium, hal yang dapat mencegah timbulnya kanker ovarium, serta hal yang dapat menurunkan risiko terjadinya kanker ovarium. Tingkat pendidikan dan pekerjaan responden dirangkum dalam Tabel 2.

Tabel 2. diketahui bahwa lebih dari separuh responden memiliki tingkat pendidikan menengah, yaitu SMP atau SMA serta sebagian besar adalah ibu rumah tangga. Hubungan antara tingkat pendidikan dengan tingkat pengetahuan mengenai kanker ovarium di-rangkum dalam Tabel 3.

Tingkat pendidikan dan tingkat pengetahuan responden mengenai kanker ovarium memiliki hubungan yang bermakna (nilai $r=8,205$ dengan $p=$ $0,038)$. Hal ini berarti rendahnya tingkat pengetahuan berhubungan dengan rendahnya tingkat pendidikan responden.

Hubungan antara pekerjaan responden dengan tingkat pengetahuan mengenai kanker ovarium dirangkum dalam Tabel 4. Pekerjaan dan tingkat pengetahuan respon-den mengenai kanker ovarium tidak memiliki hu-bungan yang bermakna (nilai $r=3,156$ dengan $p=0,093$ ). Hal ini berarti rendahnya tingkat pengeta-huan tidak dipengaruhi oleh status pekerjaan responden.

Tabel 2. Distribusi Tingkat Pendidikan dan Pekerjaan Responden

\begin{tabular}{lcc}
\hline \multicolumn{1}{c}{ Karakteristik } & $\begin{array}{c}\text { Jumlah } \\
\text { (orang) }\end{array}$ & $\begin{array}{c}\text { Persentase } \\
(\%)\end{array}$ \\
\hline Tingkat pendidikan & & \\
Rendah & 26 & 32,5 \\
Tinggi & 2 & 2,5 \\
Menengah & 52 & 65,0 \\
Pekerjaan & & \\
Ibu rumah tangga & 63 & 78,8 \\
Bekerja & 17 & 21,3 \\
\hline
\end{tabular}

Tabel 3. Hubungan Tingkat Pendidikan dengan Tingkat Pengetahuan

\begin{tabular}{lcccccc}
\hline \multirow{2}{*}{ Tingkat pendidikan } & \multicolumn{3}{c}{ Tingkat pengetahuan } & \multirow{2}{*}{ Total } \\
\cline { 2 - 6 } & \multicolumn{2}{c}{ Kurang } & \multicolumn{2}{c}{ Cukup } & \multicolumn{2}{c}{} \\
\cline { 2 - 6 } & $\mathbf{n}$ & $\%$ & $\mathbf{n}$ & $\%$ & $\mathbf{n}$ & $\%$ \\
\hline Menengah ke bawah & 64 & 82,1 & 14 & 17,9 & 78 & 100 \\
Tinggi & 0 & 0 & 2 & 100 & 2 & 100 \\
Total & 64 & 80 & 16 & 20 & 80 & 100 \\
\hline
\end{tabular}

Tabel 4. Hubungan Pekerjaan dengan Tingkat Pengetahuan

\begin{tabular}{lccccccc}
\hline \multirow{2}{*}{ Pekerjaan } & \multicolumn{4}{c}{ Tingkat Pengetahuan } & \multirow{2}{*}{ Total } \\
\cline { 2 - 5 } & \multicolumn{2}{c}{ Kurang } & \multicolumn{2}{c}{ Cukup } & & \\
\cline { 1 - 5 } & n & $\%$ & n & $\%$ & n & $\%$ \\
\hline Ibu rumah & 53 & 84,1 & 10 & 15,9 & 63 & 100 \\
tangga & 11 & 64,7 & 6 & 35,3 & 17 & 100 \\
Bekerja & 64 & 80 & 16 & 20 & 80 & 100 \\
Total & & & & & & \\
\hline
\end{tabular}

\section{DISKUSI}

Sebagian besar subjek penelitian memiliki pengetahuan yang kurang mengenai kanker ovarium. Hasil ini sama dengan hasil penelitian pada wanita di Colorado, Amerika Serikat yang menemukan bahwa sebagian besar wanita memiliki kesadaran dan tingkat pengetahuan yang kurang mengenai gejala kanker ovarium. ${ }^{10}$

Adanya hubungan yang bermakna antara tingkat pendidikan dengan tingkat pengetahuan responden dalam penelitian ini sesuai dengan penelitian yang dilakukan pada ibu-ibu rumah tangga di Desa Rukoh dimana terdapat korelasi yang tinggi antara tingkat pendidikan dengan pengetahuan mengenai kesehatan reproduksi. ${ }^{11}$ Hasil ini juga sesuai dengan teori yang dikemukakan Notoatmodjo bahwa pendidikan akan mempengaruhi kognitif seseorang dalam peningkatan pengetahuan meskipun sebenarnya pengetahuan tidak dibentuk hanya oleh pendidikan saja tetapi ada subbidang lain yang juga akan mempengaruhi pengetahuan seseorang misalnya pengalaman, informasi, keperibadian dan lainnya, sehingga bila pendidikan rendah, maka kemungkinan tingkat pengetahuan juga rendah. ${ }^{12}$ Rendahnya pengetahuan terkait tingkat pendidikan ini perlu menjadi perhatian serius karena berdasarkan penelitian di Swedia, insidensi kanker ovarium pada wanita yang mengenyam pendidikan tinggi $(0,74)$ adalah lebih rendah daripada wanita yang tidak mengenyam pendidikan tinggi $(0,98) .{ }^{13}$

Tidak adanya hubungan yang bermakna antara pekerjaan responden dengan tingkat pengetahuan mengenai kanker ovarium mungkin disebabkan bahwa pengetahuan bisa didapat dengan cara mendengarkan, melihat, merasa, bertukar pikiran dan sebagainya yang merupakan bagian dari pengindraan manusia, sesuai teori Notoatmodjo. ${ }^{12}$ Meskipun ibu rumah tangga kemungkinan tidak sering pergi ke luar rumah namun mereka tetap dapat berinteraksi dengan banyak orang secara langsung maupun melalui media sosial atau media massa 
sehingga bisa saja memiliki pengetahuan yang lebih baik daripada ibu yang bekerja. Ibu yang bekerja kemungkinan lebih sering pergi ke luar rumah dibandingkan ibu rumah tangga, namun belum tentu berinteraksi dengan orang yang lebih tahu mengenai kanker ovarium sehingga tingkat pengetahuannya juga tidak lebih baik daripada ibu rumah tangga.

Sebuah hasil penelitian menunjukkan bahwa terdapat risiko yang lebih besar untuk mengalami kanker ovarium tipe epitel pada wanita dengan pekerjaan yang berkaitan dengan mengajar (teaching occupation). ${ }^{14} \mathrm{Hal}$ ini menunjukkan bahwa bahkan wanita yang pekerjaannya sangat dekat dengan membaca dan meningkatkan ilmu pengetahuan pun tetap memiliki risiko untuk menderita kanker ovarium, padahal akses mereka untuk memperoleh pengetahuan semestinya lebih besar daripada wanita yang tidak bekerja ataupun bekerja di bidang yang tidak berkaitan dengan mengajar.

\section{SIMPULAN}

Tingkat pengetahuan mengenai kanker ovarium dipengaruhi oleh tingkat pendidikan namun tidak dipengaruhi oleh pekerjaan responden.

\section{DAFTAR PUSTAKA}

1. Dorland WA dan Newman. 2011. Kamus Saku Kedokteran Dorland.Jakarta: EGC Hal.179.

2. WHO. 2012. Estimate Cancer Incidence Mortality and Prevalence World in 2012. (Http://www.globocan.iarc.fr, diakses 4 Agustus 2016).

3. Indrawati M. 2009. Bahaya Kanker bagi Wanita dan Pria. Pendidikan untuk Kehidupan. Jakarta, Indonesia. -
4. Kemenkes RI. 2007. Pedoman Pengendalian Penyakit Kanker. Jakarta, Indonesia. -

5. Sihombing $\mathrm{M}$ dan Sirait AM. Angka Ketahanan Hidup Penderita Kanker Ovarium di RS Dr. Cipto Mangunkusumo Jakarta. Majalah Kedokteran Indonesia. 2007;57(10):346-352.

6. Pusat Data dan Informasi Kementerian Kesehatan RI. 2015. Situasi Penyakit Kanker. Jakarta.

7. American Cancer Society. 2013. What are The Risk Factor for Ovarian Cancer?. (http://www.cancer.org, diakses 21 Juni 2016).

8. Sueblinvong $\mathrm{T}$ dan Carney ME. Current Understanding of Risk Factors for Ovarian Cancer, 2009; 10 (1-2): 67-81

9. Fachlevy AF, Abdullah Z dan Russeng SS. Faktor Risiko Kanker Ovarium di RSUP Wahidin Sudirohusodo Makassar. Universitas Hasanuddin, Makasar, Indonesia. 2012. http://pasca.unhas.ac.id/jurnal

10. Goldstein CL, Susman EP, Lockwood S, Medlin EE dan Behbakht K. Awareness of Symptoms and Risk Factors of Ovarian Cancer in a Population of Women and Healthcare Providers. Clin J Oncol Nurs, 2015; 19 (2): 206-212.

11. Asiah MD. Hubungan Tingkat Pendidikan dengan Pengetahuan Kesehatan Reproduksi Ibu Rumah Tangga di Desa Rukoh Kecamatan Syiah Kuala Banda Aceh. Jurnal Biologi Edukasi, 2009; 1 (2): 1-4.

12. Notoatmodjo S. 2007. Promosi Kesehatan dan Ilmu Perilaku. Jakarta: PT. Rineka Cipta.

13. Hemminki $\mathrm{K}$ dan Li X. Level of Education and the Risk of Cancer in Sweden. Cancer Epidemiology, Biomarkers and Prevention. 2003; 12 (8): 796-802.

14. Le ND, Leung A, Brooks-Wilson A, Gallagher RP, Swenerton KD, Demers PA, et al. Occupational Exposure and Ovarian Cancer Risk. Cancer Causes Control. 2014;25(7):829-841. 